\title{
FACTORS INFLUENCING CONSUMER INTENTION AND DECISION TO PURCHASE PLASTIC WASTE RECYCLE MACHINE
}

\author{
Mohammad Baedowy"), Ujang Sumarwan**), and Iwan Setiawan*) \\ *) School of Business, IPB University \\ Jl. Pajajaran, Bogor 16151, Indonesia \\ ${ }^{* *}$ Department of Family and Consumer Sciences, Faculty of Human Ecology, IPB University \\ Jl. Dramaga, IPB Darmaga Campus, Bogor 16680, Indonesia
}

\begin{abstract}
About 1.42 million tonnes of plastic waste in Indonesian waters are unable to manage every year. Plastic waste recycling machine may be the solution to this environmental problem. Marketing strategy is required to answer the challenge in the sale of plastic waste recycling machine. This research aims to identify and analyse the factors that influence the interest of purchasing intention and purchasing decision of plastic waste recycling machine manufactured by PT Majestic Buana Group. The research was conducted for eight months from February to September 2019. Primary data were obtained through online questionnaires, while secondary data were gathered from literature, journals, and research reports. This research used purposive sampling, with a sample number of 100 respondents who have purchased the plastic recycling machine from PT. MBG from the last 5 years. Data was then processed using descriptive analysis and Structural Equation Modelling-Partial Least Square (SEM-PLS). The results show that product variables, processes, service quality have a significant influence on the purchase interest while product variables, service quality and company reputation significantly affects purchasing decisions.
\end{abstract}

Keywords: marketing mix, SEM PLS, purchasing intention, plastic waste, recycling machine

Abstrak: Sekitar 1,42 juta ton sampah plastik yang berada di perairan Indonesia setiap tahun tidak dapat tertangani. Produk mesin daur ulang sampah plastik mungkin menjadi solusi bagi permasalahan lingkungan ini. Strategi pemasaran diperlukan untuk menjawab tantangan dalam penjualan mesin daur ulang sampah plastik. Penelitian ini bertujuan untuk mengidentifikasi dan menganalisis faktor-faktor yang memperngaruhi minat pembelian dan keputusan pembelian mesin daur ulang sampah plastik di PT Majestik Buana Group. Penelitian dilakukan selama 8 bulan dari Februari sampai September 2019, di lokasi pabrik daur ulang sampah plastik PT. MBG di Kota Bekasi. Data primer diperoleh melalui kuesioner secara online, sementara data sekunder diperoleh dari literatur, jurnal, dan laporan-laporan penelitian. Teknik pengambilan sampel dalam kajian ini menggunakan purposive sampling, dengan jumlah sampel sebanyak 100 orang responden yang telah melakukan pembelian Mesin daur ulang plastik produksi PT. MBG. Data kemudian diolah menggunakan analisis diskriptif dan Structural Equation Modelling-Partial Least Square (SEM-PLS). Hasil menunjukkan bahwa variabel produk, proses, kualitas layanan memiliki pengaruh yang signifikan terhadap minat pembelian sementara variabel produk, harga, kualitas layanan dan reputasi perusahaan secara signifikan berpengaruh terhadap keputusan pembelian.

Kata kunci: bauran pemasaran, SEM PLS, minat pembelian, sampah plastik, mesin daur ulang

\footnotetext{
${ }^{1}$ Corresponding author:

Email:mbaedowy@gmail.com
} 


\section{INTRODUCTION}

Solid Waste Management has emerged into global issue and likely to cause a threat to the environment and public health (Wilson et al. 2015). Waste management becomes a key challenge to environmental management for many countries in the world, especially to urban areas in developing countries (Diaz and Otoma, 2014). Indonesia, as a developing country, faces serious problems managing its solid waste, especially plastic waste. Indonesia produces approximately 5.4 million metric tons of plastic waste (Aschuri et al. 2016), well over $14 \%$ of the country's total solid waste generation. Among other types of solid waste, plastic waste listed as the second most generated waste in Indonesia after organic waste (Kehutanan, 2019). Jambeck et al. (2015) stated that Indonesia is one of the main contributors to the world's ocean plastic waste with estimated plastic waste dumped into the sea ranging from 0.48 to 1.29 million metric tons per year. Plastic waste in oceans mainly comes from solid waste generation in land activities, e.g. tyres, textiles materials, paints, health and cleaning, and other decomposed materials such as shoe sole, synthetic grass) (Jambeck et al. 2015; Boucher and Friot, 2017)

Through presidential regulation No. 97/2017, Indonesia has committed to reducing the amount of plastic waste in the sea by $70 \%$ in 2025 , through the handling of waste by recycling plastic waste (Indonesia, 2017). Plastic waste has always been considered useless and doesn't have any economic values at all. However, with re-recycling plastic waste into a semi-finished raw material, it makes it an advanced industrial raw material. The industrial sector of plastic waste recycling can increase the value-added for the community economy and a foreign exchange producer for the country through the export of recycled plastic waste products that in the year 2019 predicted at USD 441.3 million (Perindustrian, 2019).

PT. Majestic Buana Group manufactures plastic waste recycling machines that have an excellent proposition value, making consumers interested in purchasing the machines. The right machine design, lifetime machine performance guarantees, free training, and guaranteed purchase of production results are among the propositions. Also, the advantage of the machine lies in the ease of operation, safety, and the effectiveness of top engine work. The problem faced by the company is that in the last ten years the sale of plastic waste recycling machine showed a positive trend, but the change is not significant and stagnates which ranges from 60 units/ year in the last five years. This kind of sales trend is a problem for the company since it affects corporate income. One attempt taken by the company to tackle this issue is by making a study of marketing strategies on the behaviour of consumers (buyers).

The research questions proposed in this research are: what are the general characteristics of the plastic waste recycling machine consumers at PT. MBG? What are the factors that affect the purchasing interest of plastic waste recycling machine at PT. MBG? What are the factors that affect the purchase decision of plastic waste recycling machine at PT. MBG? This research tried to identify and review factors that affect the purchase decision of plastic waste recycling machine in PT. MBG from the side of consumer behaviour and marketing aspects.

\section{METHODS}

This research was conducted from February to September 2019. Primary data was obtained through online questionnaires, while the secondary data was collected from the literature, journals, and research reports relevant to the study material. This study uses purposive sampling with a sample number of 100 respondents who have purchased the plastic waste recycling machine from PT. MBG. The respondents were taken from a list of buyers who live in Indonesia and have purchased the products within the last 5 years, both individual buyers and institutional buyers.

This study focuses on consumer behaviour that is influenced by marketing strategies. Marketing strategy is formulated based on marketing mix, i.e. product features (product), price, promotion and place (place), often referred to as 4Ps. However, according to Supranto and Limakrisna (2011), in addition to 4P, 3Ps in services can also provide more value to the consumer. Therefore, this research begins with the analysis of the marketing strategy of plastic waste recycling machine with the concept of marketing mix 7P coupled with variable quality service and company reputation.

Descriptive analysis and Structural Equation ModellingPartial Least Square (SEM-PLS) were used in the analysis. SEM PLS Descriptive analysis was used to describe the respondent characteristics while SEM 
PLS was used to determine the indicators that affect the variable and then to test the hypothesis on variables affecting purchasing interests and decisions of plastic waste recycling machines manufactured by PT. MBG. The model in this research is shown in Figure 1. There are 19 independent variables that hypothetically influence the purchase intention, they are Product. Price, Place, Promotion, People, Process, Physical Evidence, Quality Service and Reputation. Purchase decision, is influence by 10 independent variables, i.e., Product. Price, Place, Promotion, People, Process, Physical Evidence, Quality Service, Reputation, and Purchase Intention. Based to above research, the hypothesis built in this research are:

H1: Product has a significant positive effect on the purchasing interest.

H2: Price has a significant positive effect on the purchase interest

H3: Place has a significant positive influence on purchasing interest

H4: Promotion has a significant positive effect on purchasing interest

H5: People has significant positives on purchasing interest

H6: Process has significant positive effect on purchasing interest
H7: Physical evidence significantly positively affects the purchasing interest

H8: The company's reputation has a significant positive effect on purchasing interest

H9: Quality of service has significant positive effect on the purchasing interest

H10: Product has a significant positive effect on purchasing decisions.

H11: Price has a significant positive effect on purchasing decisions

H12: Place has a significant positive impact on purchasing decisions

H13: Promotion has significant positive against purchasing decisions

H14: People has significant positives on purchasing decisions

H15: Process has significant positive impact on purchasing decision

H16: Physical evidence has significant positive effect on purchasing decisions

H17: Company's Reputation has significant positive effect on purchasing decisions

H18: Service quality has significant positive effect on purchasing interest

H19: Purchase interest has positive influence to purchasing decisions

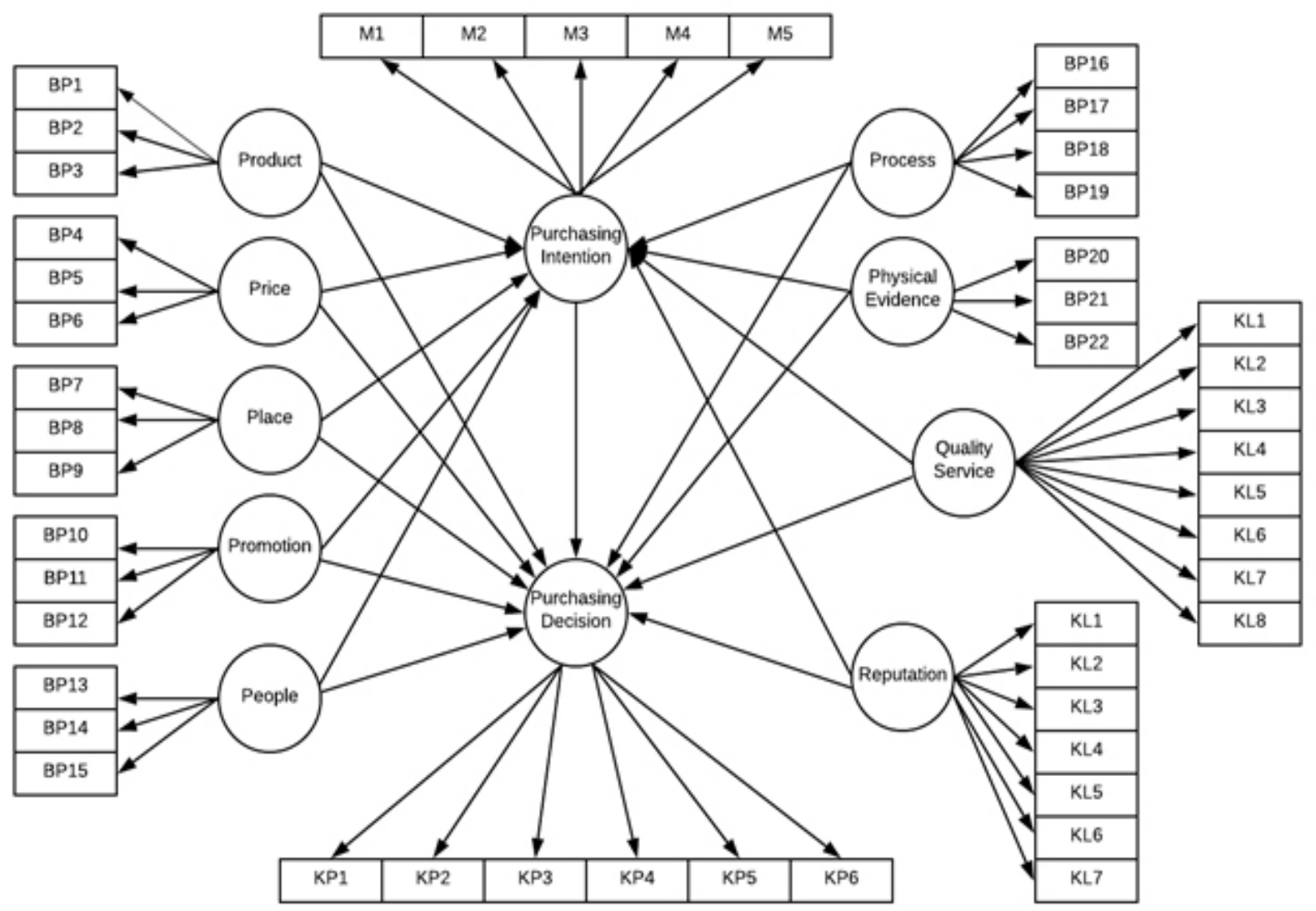

Figure 1. Research model 


\section{RESULTS}

\section{Respondent Characteristics}

The primary and majority type of respondents who have purchased are individual buyers (81\%) followed by company/institutional buyers. Most respondents' age is at 21-30 years old (37\%), and the education level is mostly college graduate. The most respondent work in private sectors $(61 \%)$ followed by respondents who work as entrepreneurs (27\%). Table 1 shows the Characteristics of respondents in this study. The respondents who took part in this research were from Indonesia and live in Indonesian territory. Respondents know the information regarding the majority of PT. MBG from various sources as described in Table 2

\section{Model Fit Measurement}

Model fit measurement is defined by testing the validity and reliability of the outer model. Outer model analysis specifies the relationship between the latent variable and its indicators, which is used to test the validity. A value larger than 0.7 or 0.5 and the Average Variance Extracted (AVE) is bigger than 0,5 with communality $>$ 0,5 , suggest that the indicator is valid (Ghozali, 2012). The reliability in SEM-PLS could be determined from the composite reliability and Cronbach's Alpha values, which should be larger than 0.6

\section{Factors affecting purchasing interest and buying decisions}

Table 3 shows the outer loading value of each indicator of the latent variable. An indicator is considered valid if it has an outer loading value greater than 0.6 . Indicators with the highest outer loading value indicate that the indicator is the indicator that can most reflect the influence of each latent variable towards the purchasing interest and decision.

\section{Evaluation of Measurement Model (Outer Model)}

Product

The result of an outer loading of the product variable shows that the indicator's value is bigger than 0.6, indicating a valid one. BP1 has the highest value of outer loading than the other indicators of 0.930 . This result indicates that the indicator (the quality of plastic waste recycling machine PT. Majestic Buana Group Both during Operation process) is a question that most reflects product variable.

Table 1. Respondents Characteristics

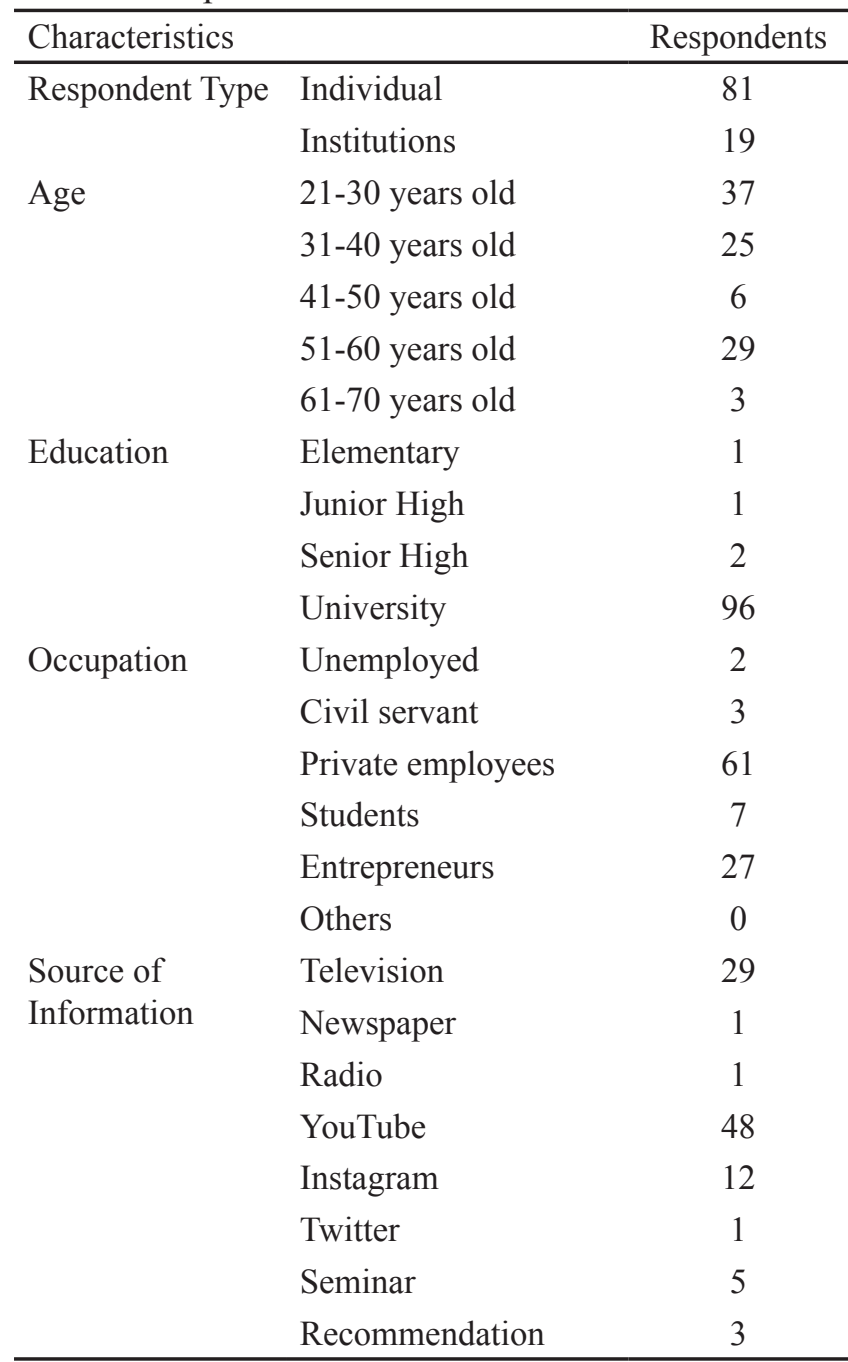

Table 2. Respondents' residential

\begin{tabular}{lc}
\hline Area & No of Respondents \\
\hline Sumatra & 17 \\
West Java & 12 \\
Jakarta & 11 \\
Central Java & 17 \\
East Java & 21 \\
Borneo & 6 \\
Bali & 2 \\
Sulawesi & 9 \\
Nusa Tenggara & 2 \\
Papua & 3 \\
\hline
\end{tabular}


Table 3. Outer loading for each indicator on each variable

\begin{tabular}{|c|c|c|}
\hline Variabel & Indicator & Outer Loading \\
\hline \multirow[t]{3}{*}{ Product } & BP1. Quality & 0.930 \\
\hline & BP2. Ease of Maintenance & 0.904 \\
\hline & BP3. Spare parts & 0.914 \\
\hline \multirow[t]{3}{*}{ Price } & BP4. Competitive Pricing & 0.885 \\
\hline & BP5. Value equals to benefits & 0.907 \\
\hline & BP6. Pricing equals to features & 0.875 \\
\hline \multirow[t]{3}{*}{ Place } & BP7. Locations & 0.832 \\
\hline & BP8. Safe locations & 0.816 \\
\hline & BP9. Accessible & 0.779 \\
\hline Promotion & BP12. Additional Services & 1.000 \\
\hline \multirow[t]{3}{*}{ People } & BP13. Informative team & 0.911 \\
\hline & BP14. Responsive team & 0.908 \\
\hline & BP15. Problem solving team & 0.901 \\
\hline \multirow[t]{4}{*}{ Process } & BP16. Easy to start a business & 0.899 \\
\hline & BP17. after sales services & 0.884 \\
\hline & BP18. Payment Access & 0.908 \\
\hline & BP19. Well and on time services & 0.911 \\
\hline \multirow{3}{*}{$\begin{array}{l}\text { Physical } \\
\text { Evidence }\end{array}$} & BP20. Comfortable room & 0.858 \\
\hline & BP21. Adequate toilets & 0.860 \\
\hline & BP22. Wide parking area & 0.867 \\
\hline \multirow[t]{8}{*}{ Service Quality } & KL1. Responsive in services & 0.883 \\
\hline & KL2. Mounting up guarantee & 0.892 \\
\hline & KL3. Machine guarantee & 0.877 \\
\hline & KL4. Competent and skillful employees & 0.811 \\
\hline & KL5. Friendly and polite employees & 0.897 \\
\hline & KL6. Employees have qualities and capabilities & 0.899 \\
\hline & KL7. Employees have high empathy & 0.895 \\
\hline & KL8. Employees have high knowledge berpengetahuan for consumer leads & 0.901 \\
\hline \multirow{7}{*}{$\begin{array}{l}\text { Company } \\
\text { Reputation }\end{array}$} & RP1. PT. MBG is regularly seen on social media & 0.886 \\
\hline & RP2. Popularity of PT. MBG owner is widely known & 0.897 \\
\hline & RP3. The owner does the socialization & 0.890 \\
\hline & RP4. Machines maufactured by PT. MBG have great quality & 0.878 \\
\hline & RP5. PT. MBG is trusted in manufacturing plastic waste recycling machines & 0.884 \\
\hline & RP6. Companies can fulfill its promises & 0.876 \\
\hline & RP7. Owners reputation is known more than the company's reputation & 0.888 \\
\hline \multirow{5}{*}{$\begin{array}{l}\text { Purchase } \\
\text { Intention }\end{array}$} & M1. Consumer's attention & 0.899 \\
\hline & M2. Consumer's interest & 0.903 \\
\hline & M3. Consumer's desire & 0.900 \\
\hline & M4. Purchasing Plastic waste recycling machines (action) as the best options & 0.905 \\
\hline & M5. Have purchased machines manufactured by PT. MBG in less than 6 months & 0.881 \\
\hline \multirow{6}{*}{$\begin{array}{l}\text { Purchasing } \\
\text { Decision }\end{array}$} & KP1. Machine suits the need & 0.916 \\
\hline & KP2. Clear information searches & 0.900 \\
\hline & KP3. alternative evaluation on machines variation is available & 0.885 \\
\hline & KP4. Machine purchasing according to the needs & 0.882 \\
\hline & KP5. Providing recommendation to others & 0.912 \\
\hline & KP6. Purchasing based on people's recommendations & 0.892 \\
\hline
\end{tabular}


Price

The indicators in variable price are valid because their values are greater than 0.6. The indicator with the highest outer loading value is BP5 (0.907), indicating that the indicator is a question that most capable of reflecting the price variable price.

\section{Place}

The place variable indicators have values bigger than 0.6 , hence, valid. BP7 is an indicator with the highest value of 0.832 , shows that the indicator (the sales location of plastic waste recycling machine PT. Majestic Buana Group is easily accessible) is a question that can best reflect the place variables.

\section{Promotion}

BP12 has an outer loading value greater than 0.6. Therefore, it is valid. The indicator (the company offers additional services that benefit prospective buyers on the purchase of plastic waste recycling machine PT. Majestic Buana Group) is also a question that can best reflect the promotion variable.

\section{People}

The indicators in the people variable are valid because they have values larger than 0.6. The highest value indicator is BP13, indicating that the indicator represented by the company's question has an informative team most capable of reflecting the people variable.

\section{Process}

The process variable is valid since it has an outer loading value greater than 0.6 . The highest indicator is BP19, that shows the company provide overall excellent and timely service is a question that can best reflect the impact of the process variable

\section{Physical Evidence}

An outer loading value higher than 0.6 in each physical evidence variable indicator indicates that the indicators are valid. BP22 has the highest rating of 0.867 indicating that the indicator (the company has an adequate parking lot for prospective buyers) is a question that can best reflect the physical evidence variable
Quality Services

The service quality variable indicators are declared valid because they have an outer loading value greater than 0.6. The KL8 indicator with a value of 0.901 is an indicator with the highest value of 8 indicators. This result implies that the employee of PT. Majestic Buana Group has the knowledge and information or knows prospective buyers quite well to understand the need for potential buyers. it is seen as the most reflective question on the Quality service variable.

\section{Company Reputation}

The company's reputation variable indicator can be said to be valid because it has an outer loading value greater than 0.6. Of the seven indicators, RP2 is the highest value indicator of 0.897 . This means that the indicator (the popularity of the owner of PT. Majestic Buana Group is widely known) is a question that can best reflect the company's reputation variable.

\section{Purchasing Intention}

The purchase interest variable has valid indicators because it has an outer loading value greater than 0.6. The M4 indicator with a value of 0.905 is the indicator with the highest outer loading value compared to other indicators. This result shows that the M4 indicator (I purchased the plastic waste recycling machine PT. Majestic Buana Group as the best choice) is a question that can best reflect the purchasing intention variable.

\section{Purchasing Decision}

The outer loading value greater than 0.6 on each indicator indicates that the six-indicator variable purchase decision is said to be valid. KP1 is an indicator with the highest value indicating that the question most capable of reflecting the purchasing decision variable.

The inner model is used and analyzed to reveal the relationship between variables. Table 4 shows the evaluation of structural model (inner model) among variables used in this research. $\mathrm{H} 0$ will be rejected if the $\mathrm{T}$ statistics is greater than 1.96 (with $95 \%$ Confidence Interval and 5\% error) and $\mathrm{P}$ value smaller than 0.05 . Original sample is used as an indicator to find out the direction of the impact. A positive original sample marks positive relationship between latent variables and vice versa. 
Table 4. Original sample, $t$ value, dan $\mathrm{p}$ value recapitulation

\begin{tabular}{|c|c|c|c|}
\hline Variable Relationship & Original Sample $(\mathrm{O})$ & T statistics $(|\mathrm{O} / \mathrm{STDEV}|)$ & P values \\
\hline Product $\rightarrow$ Purchasing Intention & 0.200 & $2.333^{* *}$ & $0.008^{* *}$ \\
\hline Price $\rightarrow$ Purchasing Intention & 0.031 & 0.239 & 0.461 \\
\hline Place $\rightarrow$ Purchasing Intention & -0.044 & 1.060 & 0.346 \\
\hline Promotion $\rightarrow$ Purchasing Intention & -0.022 & 0.677 & 0.617 \\
\hline People $\rightarrow$ Purchasing Intention & -0.099 & 0.536 & 0.692 \\
\hline Process $\rightarrow$ Purchasing Intention & 0.296 & $2.853 * *$ & $0.004^{* *}$ \\
\hline Physical evidence $\rightarrow$ Purchasing Intention & 0.069 & 1.655 & 0.124 \\
\hline Quality Services $\rightarrow$ Purchasing Intention & 0.533 & $4.242 * *$ & $0.000^{* *}$ \\
\hline Company Reputation $\rightarrow$ Purchasing Intention & 0.024 & 0.179 & 0.679 \\
\hline Product $\rightarrow$ Purchasing Decision & 0.243 & $3.248^{* *}$ & $0.000^{* *}$ \\
\hline Price $\rightarrow$ Purchasing Decision & 0.205 & $1.818^{* *}$ & $0.004 * *$ \\
\hline Place $\rightarrow$ Purchasing Decision & 0.01 & 0.285 & 0.968 \\
\hline Promotion $\rightarrow$ Purchasing Decision & -0.007 & 0.237 & 0.803 \\
\hline People $\rightarrow$ Purchasing Decision & -0.042 & 0.259 & 0.942 \\
\hline Process $\rightarrow$ Purchasing Decision & 0.101 & 1.001 & 0.659 \\
\hline Physical Evidence $\rightarrow$ Purchasing Decision & 0.006 & 0.168 & 0.727 \\
\hline Quality Services $\rightarrow$ Purchasing Decision & 0.255 & $2.460 * *$ & $0.033^{* *}$ \\
\hline Company Reputation $\rightarrow$ Purchasing Decision & 0.196 & $1.991 * *$ & $0.079^{*}$ \\
\hline Intention $\rightarrow$ Purchasing Decision & 0.04 & 0.436 & 0.488 \\
\hline
\end{tabular}

Note: ** significantly affect at $\alpha=0,05 ; *$ significantly affect at $\alpha=0,1$

H1: Product has positive and significant influence on purchasing Intention (H0 Rejected).

According to Table 3, the product's impact on the purchase interest has the $\mathrm{P}$-value of 0.008 and the $\mathrm{T}$ statistical value of 2.333. The P-value (0.008) is less than the $\alpha=$ 0.05 , and the $\mathrm{T}$ statistic is higher than the $\mathrm{T}$ value of the table (1.98) which signifies that $\mathrm{H} 1$ is accepted, which means that product variable influence is significant to purchasing interest. Then, the original value of this product variable sample is positively valued at 0.200 . This suggests that increasing the product variable by $100 \%$ will increase the interest in purchasing by $20 \%$. This research is in accordance to Herdioko (2018) stating that the product has positive and significant impact to the purchasing intention when browsing to the Otten coffee website. Margaretha (2011) stated that a well described "product" which is a Master Programme at a university, becomes the main consideration on people's purchasing intention.

H2: Price does not havehas positive and significant influence on purchasing intention (H0 Accepted)

$\mathrm{P}$-value in the price variable is 0.461 , and the $\mathrm{T}$ statistical value is 0.239 . Price has no significant effect on the interest of purchases. The P-value (0.461) is larger than the $\alpha$ value $=0.05$, and the $\mathrm{T}$ statistic is smaller than the T-value table (1.98) which signifies that $\mathrm{H} 0$ is accepted that the product price has no significant effect on the purchasing interest. This result suggests that prospective buyers who are interested in this product do not consider the price aspect of the product.

H3: Place have positive significant influence on purchasing intention (H0 Accepted)

In terms of place or place variables, the $\mathrm{P}$ value is 0.346 and the $\mathrm{T}$ statistical value is 1.060 . The $\mathrm{P}$ value $(0.346)$ is larger than the $\alpha$ value $=0.05$ and the T statistic is smaller than the T-value table (1.98) indicating that the place has no significant effect on the purchasing interest.

H4: Promotion have positive significant influence on purchasing intention (H0 Accepted)

In terms of promotion, a $\mathrm{P}$ value of 0.617 and $\mathrm{T}$ statistical value of 0.677 is obtained. The $\mathrm{P}$-value (0.617) is larger than the $\alpha$ value $=0.05$, and the T statistic is smaller than the T-value of the table (1.98) indicating that the promotion has no significant effect on the purchase interest. This result is because of the company PT. Majestic Buana Group does not conduct promotion through print media, TV, and online media. 
H5: People have positive and significant influence on purchasing Intention (H0 Accepted)

In the person or people variable, the P-value is 0.692 , and the $\mathrm{T}$ statistical value is 0.536 . The $\mathrm{P}$-value $(0.692)$ is larger than the $\alpha$ value $=0.05$, and the T statistic is smaller than the T-value table (1.98) which signifies that the person variable has no significant effect on the purchasing interest.

H6: Process has positive and significant influence on purchasing intention (H0 Rejected)

In the process variable, the P-value is 0.004 , and the $\mathrm{T}$ statistical value is 2.853 . The $\mathrm{P}$-value $(0.004)$ is smaller than the $\alpha$ value $=0.05$, and the T statistic is higher than the T value of the table (1.98) which signifies that the process variable significantly affects the interest of the purchase. Then, the original value of the variable sample process is positively valued at 0.296 . These results indicate that an increased process variable of $29.6 \%$ will increase the interest in purchases by $31 \%$. Dhiba and Maduwinarti (2014) stated that the process variables have a positive and significant influence on the interest of visitors to the attractions of Dr Adhyatama Health Museum. It happens because there are proper management and excellent service process that affects the interest of consumers. Process is also seen as an important factor especially when people has limited knowledge on a service or product as stated by Weerasiri (2016) regarding buying intention for motorcycle insurance.

H7: Physical evidence has positive and significant influence on purchasing intention (H0 Accepted)

In physical evidence or physic variables, a $\mathrm{P}$-value value of 0.124 is obtained and a statistical $\mathrm{T}$ value of 1.655 . The P-value (0.124) is larger than the $\alpha$ value $=0.05$, and the $\mathrm{T}$ statistic is less than the T-value table (1.98) which indicates that the physical proof variable has no significant effect on purchasing interest.

H8: Company Reputation has positive and significant influence on purchasing intention (H0 Accepted)

In the company's reputation variable, there is a $\mathrm{P}$-value of 0.679 and a statistical T value of 0.179 . The P-value (0.679) is higher than the $\alpha$ value $=0.05$, and the $\mathrm{T}$ statistic is smaller than the T-value of the table (1.98) which indicates that the company's reputation variable has no significant effect on purchasing interest.
H9: Service Quality has positive and significant influence on purchasing intention (H0 Rejected)

In the service quality variable, a $\mathrm{P}$ value of 0.000 is obtained and a statistical T value of 4.242. The P-value (0.000) is smaller than the $\alpha=0.05$ value, and the T statistic is higher than the T-value of the table (1.98) which signifies that the service quality variable significantly affects the interest of the purchase. The original value of this quality variable sample service is positive at 0.533 . This result indicates that increasing the service quality variable by $100 \%$ will increase the interest in purchases by $53.3 \%$. Another research conducted by Saidani and Arifin (2012) about factors that influence the interest of purchasing in Ranch Market, the study stated that the quality of service was positively and significantly influential in consumer buying interest. While Suryawardan and Yani (2015) conducted similar research regarding the purchasing interest on public refuelling stations, the results of the study stated that the quality of service variables positively and significantly affect the interest of purchases acceptable.

H10: Product has positive and significant influence on purchasing decision (H0 Rejected)

The effect of products on purchasing decisions has a $P$ value of 0.000 and $T$ statistical value of 3.248 . The P-value (0.000) is smaller than the $\alpha$ value $=0.05$, and the $\mathrm{T}$ statistic is higher than the $\mathrm{T}$ value of the table (1.98) which signifies that the product is of significant effect to the purchase decision. The original value of this product variable sample is positively valued at 0.243 . This finding suggests that increasing the product variable by $100 \%$ will increase the purchase decision by $24.3 \%$. This result is in line with earlier studies from Nugroho et al. (2015); Pertiwi et al. (2016); Ridho et al. ( 2019)

H11: Price has positive and significant influence on purchasing decision (H0 Accepted)

In the price variable, the P-value is 0.004 , and the $\mathrm{T}$ statistical value is 1.818 . Prices have a significant effect on purchasing decisions. The P-value (0.004) is smaller than the $\alpha$ value $=0.05$, and the $\mathrm{T}$ statistic is higher than the $\mathrm{T}$ value of the table (1.98) indicating that the price of the product has no significant effect on the purchase decision. Then, the original value of this price variable sample is positively valued at 0.205 . 
This result indicates that the increased price variable by $100 \%$ will increase the purchase decision by $20.5 \%$.

H12: Place has positive and significant influence on purchasing decision (H0 Accepted).

On place or place variables, the $\mathrm{P}$-value is 0.968 , and the $\mathrm{T}$ statistical value is 0.285 . The $\mathrm{P}$-value (0.968) is higher than the $\alpha$ value $=0.05$, and the T statistic is smaller than the T-value table (1.98) indicating that the place has no significant effect on the purchase decision.

H13: Promotion has significant and positive influenceon purchasing decision (H0 Accepted)

In promotion, the $\mathrm{P}$-value is 0.803 , and the $\mathrm{T}$ statistical value is 0.237 . The P-value (0.803) is larger than the $\alpha$ value $=0.05$, and the $\mathrm{T}$ statistic is smaller than the T-value table (1.98) indicating that the promotion has no significant effect on the purchase decision.

H14: People has positive and significant influence on purchasing decision (H0 Accepted)

In the person or people variable, the P-value is 0.942 , and the T statistical value is 0.259 . The P-value $(0.942)$ is higher than the $\alpha$ value $=0.05$, and the $\mathrm{T}$ statistic is smaller than the T-value of the table (1.98) indicating that the variable of the person has no significant effect on the purchase decision.

H15: Process has positive and significant influence on purchasing decision (H0 Accepted)

In the process variable, the $\mathrm{P}$-value is 0.659 , and the $\mathrm{T}$ statistical value is 1.001 . The P-value (0.659) is higher than the $\alpha$ value $=0.05$, and the $\mathrm{T}$ statistic is smaller than the T-value table (1.98) indicating that the process variable has no significant effect on the purchase decision.

H16: Physical evidence has positive and significant influence on purchasing decision (H0 Accepted)

In the physical evidence variable or physical evidence, a $P$ value of 0.727 is obtained and a statistical T value of 0.168 . The $P$ value $(0.727)$ is greater than the $\alpha$ value $=$ 0.05 and the T statistic is smaller than the T-value table (1.98) which signifies that the physical proof variable has no significant effect on the purchase decision.
H17: Company Reputaton has positive and significant influence on purchasing decision (H0 Rejected)

In the company's reputation variable, the P-value is 0.079 and a statistical $\mathrm{T}$ value of 1.991 . The P-value (0.079) is smaller than the $\alpha$ value $=0.1$, and the $\mathrm{T}$ statistic is higher than the $\mathrm{T}$ value of the table indicating that the company's reputation variable has a significant effect on the purchase decision. Then, the original value of the variable sample of the company's reputation is positively valued at 0.196 . This result indicates that an increase in the company's reputation variable of $100 \%$ will increase the purchase decision by 19.6\%. Tjakraatmadja and Harjanti (2018) stating that the reputation of an online store is very influential in consumer confidence. The statement was strengthened by Harahap et al. (2017) stating that the reputation variable is important in purchasing decision.

H18: Service Quality has positive and significant influence on purchasing decision (H0 Rejected)

In the service quality variable, a $\mathrm{P}$ value of 0.033 is obtained and a statistical T value of 2.460 . The P-value $(0.033)$ is smaller than the $\alpha$ value $=0.05$, and the $\mathrm{T}$ statistic is higher than the $\mathrm{T}$ value of the table (1.98) which signifies that the service quality variable significantly affects the purchase decision. Then, the original value of the variable quality service is a positive value of 0.255 . This figure indicates that increasing the service quality variable by $100 \%$ will increase the purchase decision by $25.5 \%$. Other research related to purchasing decisions influenced by the quality of service conducted by Yunita and Ali (2017) shows that the quality of service is firmly and positively influence the generator purchase decision. Fahrudin and Yulianti (2015) also told that quality service was a significant factor on buying decision on Bank's products and services.

H19: Purchasing Intention has positive and significant on purchasing decision (H0 Accepted)

In the purchase interest variable, the $\mathrm{P}$ value is 0.488 , and the T statistical value is 0.436 . The $\mathrm{P}$-value $(0.488)$ is higher than the $\alpha$ value $=0.05$, and the T statistic is smaller than the T-value of the table (1.98) which signifies that the purchase intention variable has no significant effect on the purchase decision. 


\section{Managerial Implication}

The producer should focus more in products, service quality and reputation. The analysis above shows that only 3 factors that are significant and have influence on purchasing decision which is products, service quality and reputation. Based on this result, the manufacturer should manage its products, service quality and company reputation to acquire better purchasing decision for its products. In products, the company should maintain its machines' quality and also inform the potential buyer that the machines come with additional benefits, such as the ease of maintenance and the supply of spare parts. This would be seen as a benefit by potential buyers and would improve their buying decision.

Service quality should be maintained by PT Majestic Buana Group by providing more training and collaborative effort between employees and company on improving employee's knowledge and sense of services to potential buyers. A skilful, well-trained, friendly, and helpful employees in handling potential buyer's problem while also communicating the probable solution will add a huge point in buyers' purchase decision.

Reputation is also significant as stated from the analysis. The company should maintain its reputation by taking actions that will seal the reputation. Since the company has been spotted regularly in social media, a public relation action would be a considerable action when discussing waste management and recycling machines. The owner's virtuous reputation can also be a value added in promoting company's reputation in social media.

\section{CONCLUSIONS AND RECOMMENDATIONS}

\section{Conclusions}

Consumer characteristics of PT. Majestic Buana Group who have purchased are dominated by the age of 2130 years with the last education of college-level degree and work as a private employee and also entrepreneurs. The origin of the respondent is almost present in every province but mostly from Java Island. The majority of respondents who are interested in making purchases and who have made a purchase are informed about the plastic waste recycling machine products from online media sources and television. In consumers who are interested in buying plastic waste recycling machine products PT. Majestic Buana Group, the people factor, process, quality of service as well as the company's reputation, have a positive and significant impact on their buying interest. The product aspect, in the other hands, along with service quality, and the company's reputation has significant and positive influence towards purchasing decisions .

\section{Recommendations}

Based on the above research results for further research is to find factors that determine the interest of purchase and purchase decisions. PT Majestic Buana Group should identify and combine its marketing mix correctly, efficiently and effectively based on the age segmentation of prospective buyers. By communicating its strong points through various channels, potential buyers' purchasing intention and buying decision would hopefully increase and would give better result to company's machine sales.

\section{REFERENCES}

Aschuri I, Yamin A, Widyasih YD. 2016. The use of waste plastic as a partial substitution aggregate in asphalt concrete pavement. Jurnal Teknik Sipil ITB 23(1):1-6. https://doi.org/10.5614/ jts.2016.23.1.1.

Boucher J, Friot D. 2017. Primary microplastics in the oceans. Available at: https://www.iucn.org/ content/primary-microplastics-oceans.

Dhiba IDS, Maduwinarti A. 2014. Analisis pengaruh bauran pemasaran jasa terhadap minat pengunjung pada obyek wisata Museum Kesehatan Dr. Adhyatma, MPH Surabaya. Jurnal Ilmu Ekonomi dan Manajemen 1(1):94-109.

Diaz R, Otoma S. 2014. Cost-benefit analysis of waste reduction in developing countries: A simulation. Journal of Material Cycles and Waste Management 16(1):108-114. https://doi. org/10.1007/s10163-013-0148-3.

Fahrudin MF, Yulianti E. 2015. Pengaruh promosi, lokasi, dan kualitas layanan terhadap keputusan pembelian nasabah Bank Mandiri Surabaya. Journal of Business \& Banking 5(1):149. https:// doi.org/10.14414/jbb.v5i1.478.

Ghozali I. 2012. Structural Equation Modeling Metode Alternatif dengan Partial Least Square. 3rd edn. Semarang: Badan Penerbit Universitas 


\section{Diponegoro.}

Harahap DA et al. 2017. Pengaruh reputasi univeritas terhadap keputusan mahasiswa memilih studi di Universitas islam Sumatera Utara. in Forum Manajemen Indonesia 9. Semarang, pp. 1-12. https://doi.org/10.31227/osf.io/tz5yv.

Herdioko J. 2018. Pengaruh produk danharga terhadap minat beli konsumen dalam berbelanja produk kopi secara daring: studi kasus pada situs internet otten coffee. Jurnal Riset Manajemen dan Bisnis 12(2).

Indonesia PR. 2017. Kebijakan Dan Strategi Nasional Pengelolaan Sampah Rumah Tangga Dan Sampah Sejenis Sampah Rumah Tangga. Indonesia: Kementerian Sekretariat Negara Ri.

Jambeck JR et al. 2015. Plastic waste inputs from land into the ocean. Science 347(6223):768-771. https://doi.org/10.1126/science.1260352.

Kehutanan KLH. 2019. Sistem Informasi Pengelolaan Sampah Nasional, Direktorat Jenderal Pengelolaan Sampah, Limbah dan B3. http:// sipsn.menlhk.go.id/ [6 May 2019].

Margaretha Y. 2011. Analisis Pengaruh Bauran Pemasaran Jasa Terhadap Minat Beli Pada Program Magister Manajemen Universitas Kristen Maranatha. Seminar Nasional Teknologi Informasi \& Komunikasi Terapan 2011(65).

Nugroho T, Sumarwan U, Kirbrandoko K. 2015. factors influencing the purchase decision of organic tofu. Indonesian Journal of Business and Entrepreneurship (IJBE) 1(3): 115-126. https:// doi.org/10.17358/IJBE.1.3.115

Perindustrian K. 2019. Industri Daur Ulang Berkontribusi Tekan Impor Bahan Baku Plastik. Jakarta: Kemenperin.
Pertiwi MI, Yulianto E, Sunarti. 2016.Pengaruh bauran pemasaran terhadap keputusan pembelian (Survei pada konsumen Baker's King Donuts \& Coffee di MX Mall Malang). Jurnal Administrasi Bisnis 37(1):179-186.

Ridho A, Fahmi I, Jahroh S. 2019. Strategies to conquer the souvenir business: case study of lapis Talas Cake Bogor. Indonesian Journal of Business and Entrepreneurship (IJBE) 5(3):299-309. https:// doi.org/10.17358/ijbe.5.3.299.

Saidani B, Arifin S. 2012. Pengaruh kualitas produk dan kualitas layanan terhadap kepuasan konsumen dan minat beli pada ranch market. Jurnal Riset Manajemen Sains Indonesia 3(1): 1-22.

Supranto, Limakrisna N. 2011. Perilaku Konsumen dan Strategi Pemasaran. Jakarta: Mitra Wacana Media.

Suryawardan E, Yani TE. 2015. Analisis pengaruh reputasi, kualitas pelayanan dan kepercayaan terhadap keputusan pembelian pada stasiun pengisian bahan bakar umum (SPBU) di Kota Semarang. Jurnal Dinamika Sosial Budaya 17(2): 258-269. https://doi.org/10.26623/jdsb. v17i2.490.

Tjakraatmadja ATN, Harjanti D. 2018. Pengaruh reputasi dan kepercayaan terhadap keputusan pembelian secara online pada produk kosmetik di instagram. AGORA 7(1).

Weerasiri S. 2016. Impact of marketing mix on customer buying intention of motor insurance industry in Sri Lanka. Sri Lanka Journal of Marketing 2(1): 115-139.

Yunita D, Ali H. 2017. Model of purchasing decision (renting) of generator set: Analysis of product quality, price and service at PT. Hartekprima Listrindo. Scholars Journal of Economics, Business and Management 4(11): 833-841. 